Human Rights Quarterly 30 (2008) 41-75

\title{
The African Peer Review Mechanism and Human Rights: The First Reviews and the Way Forward
}

Magnus Killander*

Abstract

The African Peer Review Mechanism (APRM), one of the spin-offs of the African development framework, NEPAD, offers a unique approach to the monitoring of agreed norms of political, economic, and corporate governance in Africa. This article analyzes the APRM structure and process with a focus on how the APRM could complement other efforts to realize the African Union objective of promotion and protection of human rights. The country review reports on Ghana, Kenya, and Rwanda are analyzed from a human rights perspective.

\section{Introduction}

The African Peer Review Mechanism (APRM) is a process for assessing political, economic, and corporate governance and socioeconomic development in participating countries. The aim is to prompt states to draft a national program of action to remedy identified governance deficiencies. The review process takes place under the auspices of the African Union (AU), which replaced the Organization of African Unity (OAU) in 2002, and its development framework, the New Partnership for Africa's Development (NEPAD).

Some see the APRM as the "jewel in NEPAD's crown," others have been very critical of the APRM process and its lack of "teeth."2 Moving away from the rhetoric, this article provides a tentative analysis of the process, based on the first published country review reports. ${ }^{3}$ The focus is on how the APRM can fulfill a complementary role with regard to the promotion and protection of human rights in Africa. In what way can the APRM reinforce the African human rights system? ${ }^{4}$

The article first describes the development of the APRM. Thereafter, it considers international monitoring already existing in the governance areas covered by the APRM. Next, the APRM process is set out. The rest of the article is devoted to an analysis of the country review reports on Ghana, Rwanda, and Kenya from a human rights perspective.

\section{NEPAD and the APRM}

The NEPAD framework document was adopted by the OAU Assembly of Heads of State and Government in July 2001. ${ }^{5}$ It is the latest in a long list of development initiatives for Africa adopted since the 1960s. NEPAD does not implement projects or distribute funds. Instead, its role is to "identify problems, pinpoint solutions and where needed, exert high-level political pressure to promote change." NEPAD is led by an Implementation Committee consisting of four heads of state or government for each of the five regions of Africa. A Steering Committee 
made up of the personal representatives of the members of the Implementation Committee oversees the work of the NEPAD Secretariat.

The NEPAD framework document identifies a "vicious cycle, in which economic decline, reduced capacity and poor governance reinforce each other, thereby confirming Africa's peripheral and diminishing role in the world economy."7 To address this vicious cycle, and in particular bad governance, the NEPAD Implementation Committee meeting in Rome on 11 June 2002 adopted the Declaration on Democracy, Political, Economic and Corporate Governance (Governance Declaration) ${ }^{8}$ and a short document simply called the African Peer Review Mechanism (APRM), setting out the APRM process (APRM Base Document). ${ }^{9}$ As with the NEPAD framework document, civil society did not participate in the early stages of the development of the APRM framework. However, international donors were quick to welcome the APRM. On 27 June 2002, the G8, meeting in Canada, adopted its Africa Action Plan in which it stated that " $t$ ] $]$ he peer-review process will inform our considerations of eligibility for enhanced partnerships .... . We will not work with governments which disregard the interests and dignity of their people.”10

The APRM deals with four governance areas: democracy and political governance, economic governance and management, corporate governance, and socioeconomic development. The very broad focus on everything from peace and security to the availability of micro-credit for rural communities is unique to the APRM. However, the concept of peer review is not new. The Organisation for Economic Co-operation and Development (OECD) has been a pioneer with regard to peer review and has had some impact on how the APRM process was devised. ${ }^{11}$ Processes that could be categorized as peer reviews are also organized by the IMF, the EU ${ }^{12}$ and the $\mathrm{WTO}^{13}$ among others. ${ }^{14}$

The African Union Assembly, meeting in July 2002, adopted a Declaration on the Implementation of the New Partnership for Africa's Development, which encouraged AU members to "adopt" the Governance Declaration and accede to the APRM. ${ }^{15}$ At a meeting of the NEPAD Implementation Committee in November 2002, a Declaration of Intent to accede to the APRM was signed by Algeria, Congo-Brazzaville, Egypt, Ethiopia, Gabon, Ghana, Mali, Mauritius, Mozambique, Nigeria, Rwanda, and South Africa. ${ }^{16}$ The Implementation Committee decided that the accession process to the APRM and the "detailed criteria and indicators for measuring performance on political and economic governance" should be devised by the NEPAD Secretariat. ${ }^{17}$ At the time, the APRM was seen as "a transitional arrangement" ${ }^{\text {,18 }}$ to be established "pending the setting up of relevant institutions within the African Union."19

The next meeting of the Implementation Committee was held in Abuja, Nigeria, on 9 March 2003. The meeting approved the Memorandum of Understanding on the African Peer Review Mechanism (MoU) "as a framework for a formal accession to the APRM." 20 The MoU was signed at this meeting by Algeria, Congo-Brazzaville, Ethiopia, Ghana, Kenya, Mozambique, Nigeria, Rwanda, South Africa, and Uganda. ${ }^{21}$ As of September 2007 the MoU had been signed by twenty-seven states, more than half of the fifty-three AU member states. ${ }^{22}$

In June 2003, six persons representing the geographical regions of Africa were appointed by the NEPAD Implementation Committee to the Panel of Eminent Persons (the Panel) to oversee the peer review process and prepare the reports for discussion by the Forum of Heads of State and Government (the Forum). These were Adebayo Adedeji (Nigeria) and MarieAngelique Savané (Senegal) for western Africa, Bethuel Kiplagat (Kenya) for eastern Africa, Dorothy Njeuma (Cameroon) for central Africa, and Graca Machel (Mozambique) and Chris Stals (South Africa) for southern Africa. The representative for northern Africa, Mourad Medelci 
from Algeria, was replaced by his compatriot Mohammed Seghir Babes in May 2005 when the former was appointed Minister of Finance. The appointments to the Panel were not made in a transparent manner and there has been criticism that some of the members are too closely linked to government. ${ }^{23}$

An APRM Secretariat was established next to the NEPAD Secretariat, housed in the offices of the Development Bank of Southern Africa, in Midrand, Johannesburg, South Africa. In 2005, Dr. Bernard Kouassi, an Ivorian economist, was appointed Executive Director of the APRM Secretariat.

III. The APRM as a Complement to Existing Supervision

At the same time as the MoU was opened for signature in March 2003, the NEPAD Implementation Committee adopted a document entitled Objectives, Standards, Criteria and Indicators for the African Peer Review Mechanism (OSCI) ${ }^{24}$ Between five and nine objectives were set out for each governance area: democracy and political governance, ${ }^{25}$ economic governance and management, ${ }^{26}$ corporate governance, ${ }^{27}$ and socioeconomic development. ${ }^{28}$ The Panel further elaborated OSCI in a much longer document known as the Questionnaire, sent to all participating countries. ${ }^{29}$

The Questionnaire sets out a number of questions and indicators under each of the objectives as provided for in OSCI. The distinction between questions and indicators is often unclear. The Questionnaire has rightly been criticized for being overly complicated and for overlapping many issues. ${ }^{30}$ As discussed below, this overlap often leads to unnecessary repetition in the already lengthy reports. Sometimes, it even results in contradicting statements in the reports.

The APRM is uniquely broad in its approach to governance. However, many different international institutions monitor compliance with standards also included in the APRM documents. $^{31}$ Such monitoring of African countries, by African regional as well as global institutions, exists among others with regard to peace and security, ${ }^{32}$ elections, ${ }^{33}$ human rights, ${ }^{34}$ economic policy, ${ }^{35}$ anti-corruption measures, ${ }^{36}$ money laundering, ${ }^{37}$ labor rights, ${ }^{38}$ protection of the environment, ${ }^{39}$ trade policy, ${ }^{40}$ and human development. ${ }^{41}$

Compliance monitoring is not limited to international institutions. National watch dog institutions often play an important role, as do civil society organizations. The APRM Panel has noted: "Existing national oversight institutions should be an integral part of the national preparation for and participation in the APRM."42

\section{The APRM Review Process}

The APRM process consists of a national self-assessment and the drafting of a Program of Action (PoA) to remedy identified shortcomings. The national review process is complemented by an international review that is conducted in five stages: background study, country review mission, writing of the country review report, discussion of the report in the APRM Forum, and the tabling of the report in regional and sub-regional structures such as the Pan-African Parliament and the African Commission on Human and Peoples’ Rights. ${ }^{43}$

The APRM core documents do not say much about how participating countries should organize the national self-assessment. The Panel has produced a document entitled "Guidelines for Countries to Prepare for and to Participate in the African Peer Review Mechanism 
(APRM)."44 However, there are no clear guidelines as to the composition of the structures governing the national process, except that a national focal point shall be established and that the national structures shall be broad-based and inclusive. ${ }^{45}$

\section{A. Self-Assessment}

Based on the Questionnaire, the country conducts a self-assessment that forms the basis for a preliminary PoA. The Panel has noted the importance that the PoA "builds on, incorporates and synergises with the relevant elements of existing programmes, policies and strategies that address the key APRM objectives, e.g., PRSPs [Poverty Reduction Strategy Papers], Good Governance Programmes, Human Rights Action Plans, Gender Equity Strategies, National Development Plans, etc." ${ }^{\prime 6}$ The countries participating in the APRM process have all approached the review process differently. In particular, the extent to which civil society has been involved in the process has varied. ${ }^{47}$

In May 2003, Ghana created a Ministry of Regional Cooperation and NEPAD, which was designated as an APRM focal point. A seven-member National Governing Council (NGC) comprising of "esteemed professionals and public personalities deemed independent of the government" was created as a national equivalent to the Panel of Eminent Persons. ${ }^{48}$ A small Secretariat supports the Governing Council. From 24 to 29 May 2004, a team led by the APRM Panel member responsible for the Ghana review, Dr. Stals, visited Ghana to assess the preparations for the self-assessment and to sign a Memorandum of Understanding with the Ghanaian government. At the same time, the first national stakeholders' forum and workshop was held. The NGC appointed four research institutions to undertake the initial self-assessment for each of the four governance areas. ${ }^{49}$ In February 2005, the four research institutions submitted their reports to the NGC, which submitted a consolidated self-assessment report (CSAR) to the APRM Secretariat in March 2005 including a draft PoA.

In Rwanda, the personal representative of the President on the NEPAD Steering Committee was designated as the APRM focal point. Four technical review teams were established at a national stakeholder's workshop in March 2004. A member of the senate was given the task to preside over the review team dealing with democracy and political governance. ${ }^{50}$ As opposed to Ghana, where four organizations had been given the task to conduct the technical reviews, Rwanda chose to establish review teams composed of individuals. A National Commission to coordinate the review teams was established after a support mission in June 2004. However, the Rwandan process has been criticized for late and insufficient involvement of civil society. ${ }^{51}$ Rwanda presented its self-assessment and preliminary PoA to the APRM Secretariat in March 2005.

After Kenya signed up for the APRM in March 2003, an Inter-Ministerial Task Force was established, chaired by the APRM focal point, the Permanent Secretary in the Ministry of National Planning and National Development. In July 2004, two National Stakeholders Forums were held and a 25-member NGC was nominated from representatives of both civil society and government. After an APRM support mission visited Kenya in late July 2004, eight additional civil society members were added to the NGC. Four research institutions were selected to prepare the draft reviews of the four governance areas. ${ }^{52}$ Infighting in the NGC delayed the process but in August 2005, a self-assessment report and draft Program of Action was presented to the APRM Secretariat. Despite the problems, the Panel singled out Kenya as "a model of best practice in organizing the review process."53 
Like Rwanda, South Africa put the process firmly in the hands of the government. The Governing Council is chaired by the Minister of the Department of Public Service and Administration and the national APRM Secretariat is located in her department. ${ }^{54}$ Four organizations wrote technical assessments that were consolidated into a report. After a validation conference in May 2006, the self-assessment report was edited in a way that removed many of the critical remarks against the government, leading one observer to depict the South African process as "grossly mismanaged."

As of September 2007, Algeria and Benin had also concluded the self-assessment process. Established in March 2005 and led by a civil society representative, the Algerian National Commission (Commission Nationale sur la Gouvernance) consisted of ninety-nine members representing government, civil society, and the private sector. ${ }^{56} \mathrm{~A}$ member of civil society also led the Benin National Commission. ${ }^{57}$

\section{B. Country Review Mission}

When the self-assessment and the preliminary Program of Action have been submitted to the APRM Secretariat, it draws up an Issues Paper. If necessary, the Secretariat can undertake further technical assessment in cooperation with the country under review. The next step in the review is the country review mission. The main purpose of the mission is to "learn about the perspectives of the different stakeholders on governance in the country and to clarify the issues identified in the Issues Paper that are not taken into account in the preliminary Programme of Action of the country, and to build consensus on how these could be addressed." 58

At the time of writing, September 2007, six review missions had been undertaken. ${ }^{59}$ Dr. Stals led a sixteen-member delegation on the first country review mission to Ghana. Dr. Njeuma led the mission to Rwanda. Dr. Machel led the missions to Kenya and Professor Adedeji the mission to South Africa. Ms. Savané led the missions to Algeria and Benin. The delegations have comprised members of the APRM and NEPAD Secretariats and representatives of "partner institutions": the African Development Bank (ADB), the UN Development Program (UNDP) and the UN Economic Commission for Africa (UNECA). In addition, the missions include one to three consultants for each of the four governance areas covered. Despite being listed as a "strategic partner,"60 no representative of the African Commission on Human and Peoples' Rights participated in a mission.

\section{Country Review Reports}

At the time of writing, the country review reports on Ghana, ${ }^{61}$ Rwanda, ${ }^{62}$ and Kenya ${ }^{63}$ have been published. Under each OSCI objective, the reports set out a summary of the self-assessment followed by the findings of the country review mission and the Panel's recommendations. However, sometimes the distinction between what has been included in the self-assessment and what the mission has found is not clear. It would be helpful if the whole self-assessment report would be published when it is submitted to the APRM Secretariat. Under the current system, more than a year passes between the conclusion of a self-assessment and the eventual release of the country review report. The lack of access to the self-assessment and the preliminary Program of Action diminishes the potential influence of civil society on the process.

The draft country review report adopted by the Panel is submitted to the government, which can submit comments to be appended to the country review report. Clear factual errors in 
the review report can be corrected, but no other amendments can be made to the Panel's report which together with the government's comments and the final Program of Action is submitted to the Forum. ${ }^{64}$ Unfortunately, some of the countries reviewed so far have not included civil society in this critical stage of the development of the PoA. The scope of the governments' comments varies significantly between the reports. The Ghana response from the Office of the President is four pages, Kenya submitted a sixty-eight-page response, and Rwanda submitted thirty-nine pages of comments.

Together with its response to the report, the government submits the final PoA, which should take into account the recommendations made by the Panel in the country review report. The PoA follows the structure of the APRM objectives. It sets out required actions, indicators, means of verification, ongoing initiatives, implementing agencies, stakeholders, time frames, expected output, estimated cost, and monitoring and evaluation agencies. ${ }^{65}$ However, many provisions in the PoAs are vague and seemingly not integrated with the existing plans of the country concerned. The Ghana PoA is the only one that briefly addresses issues of stakeholder involvement, methodology, the integration of the PoA with existing programs, and follow-up. Since it is the PoA, not the self-assessment that is attached to the APRM report, it is important that these issues are addressed in the PoA.

\section{APRM Forum of the Heads of State and Government}

When the APRM Secretariat receives the comments and the revised PoA, they are attached to the country review report and distributed to the heads of state and government and other government representatives participating in the APRM Forum. Presentations are made at the Forum by the eminent person responsible for the country review and by the president of the state under review. ${ }^{66}$ At the time of writing, the reports on Ghana, Rwanda, Kenya, Algeria, and South Africa had been presented at the Forum. Some time after the Forum, the reports are published on the NEPAD and national web sites. ${ }^{67}$

With regard to the Ghana and Rwanda reports the participating states were given some time to study the reports before they were discussed at a later Forum. However, the reports on Kenya, Algeria and South Africa were discussed by the peers directly at the Forum meeting at which the reports were presented. ${ }^{68}$ The discussion among the heads of state and government is seemingly not very substantial. ${ }^{69}$ After Dr. Njeuma and President Kagame made their presentations with regard to the Rwanda review, President Obasanjo of Nigeria and chair of the Forum noted that "the areas of divergence do not seem very serious." ${ }^{\text {,70 }}$ This was despite the critical comments in the report on, for example, political diversity, discussed further below. Only one other member of the Forum commented. The President of Mozambique noted that he was impressed that corruption was not a big issue in Rwanda.

In the early days of the APRM, many of the decisions regarding the process were taken by the NEPAD Implementation Committee. The first APRM Forum was held in Kigali, Rwanda, in February 2004, with nine participating heads of state and government and representatives from five other states. With the AU Assembly of Heads of State and Government now meeting twice a year, the APRM Forum is regularly gathering as a fringe meeting, usually the day before the Assembly convenes. Seemingly, this has been done to increase the attendance of heads of state and government of the participating states.

The APRM Base Document provides that the report should be "formally and publicly tabled in key regional and sub-regional structures such as the Pan-African Parliament, the 
African Commission on Human and Peoples' Rights, the envisaged Peace and Security Council and the Economic, Social and Cultural Council (ECOSOCC) of the African Union." ${ }^{, 1}$ Seemingly the only action taken so far under this provision is that on 14 November 2006, the Executive Director and staff members of the APRM Secretariat gave short presentations on the APRM reports on Ghana, Kenya, and Rwanda to the Pan-African Parliament. After the presentations, the parliamentarians were invited to make comments. ${ }^{72}$

\section{The APRM and Human Rights}

In their rhetoric, African leaders have overwhelmingly accepted human rights. All African constitutions include a bill of rights. ${ }^{73} \mathrm{~A}$ few countries have made an effort to live up to the promise that this entails, but often the bill of rights is worth no more than the paper it is written on. African leaders have also committed themselves to human rights at the international level. African states have widely ratified UN human rights instruments. At the regional level, the OAU adopted the African Charter on Human and Peoples' Rights (African Charter) in 1981. It was ratified by all the 53 member states of the African Union (AU), the regional organization that in 2002 replaced the OAU. One of the AU's objectives is the promotion and protection of "human and peoples' rights in accordance with the African Charter on Human and Peoples' Rights and other relevant human rights instruments." ${ }^{74}$

Monitoring is necessary to ensure that a commitment to human rights becomes more than simple rhetoric. Regrettably, the regional African human rights system, with the African Commission on Human and Peoples' Rights as its main institution, has not lived up to the standards of its counterparts in Europe and the Americas. Resource constraints play an important role in this situation. The establishment of the AU has seen a proliferation of institutions with a human rights mandate. ${ }^{75}$ All of these institutions now compete for the scarce resources. If all institutions do not work together to reinforce each others' work, the commitment of the AU and its members to human rights will remain without substance.

NEPAD rests on the assumption that improved governance together with increased resources will lead to the achievement of its objective, namely to "eradicate poverty in Africa and to place African countries . . . on a path of sustainable growth and development."76 The NEPAD framework document has rightly been criticized for its lack of a rights-based approach to development and for leaving out or superficially treating important issues such as gender, HIV/AIDS, and impunity. ${ }^{77}$ The APRM framework documents are an improvement. Respect for human rights is set out as a means to reinforce development and also as an important goal in itself. The improvement in the normative framework is accompanied by an implementation mechanism that shares many features with human rights monitoring bodies. Is this unnecessary proliferation?

As mentioned above, the APRM reviews four governance areas: democracy and political governance; economic governance; corporate governance; and socioeconomic development. Human rights are relevant for all the governance areas whether referred to explicitly in the Questionnaire or not. Objective 3 under Democracy and Political Governance in the Questionnaire is entitled "promote and protect economic, social, cultural, civil and political rights, as enshrined in all African and international human rights instruments." The rights of women, children and vulnerable groups such as refugees are dealt with under separate objectives under political governance. Human rights also play an important role in the analysis of the other objectives under political governance: conflict resolution, democracy, separation of powers and 
anti-corruption measures.

Human rights are relevant not only for the discussion under political governance, but also for the other three governance areas covered by the APRM. Corporate governance includes discussion on labor and environmental rights. Socioeconomic rights, though discussed under political governance, are more extensively dealt with under socioeconomic development, though rarely using the language of human rights. The creation of a division between human rights, mainly dealt with under political governance, and socioeconomic development is not in line with current human rights and development thinking, which sees human rights and socioeconomic development (often referred to as human development) as two sides of the same coin. ${ }^{78}$

\section{Human Rights in the Country Review Reports}

Human rights are given a relatively prominent position in the APRM framework documents. The following section illustrates the extent to which human rights norms have been used to frame the issues and in the process develop appropriate Programs of Action for Ghana, Kenya, and Rwanda.

A. Implementation of Codes and Standards

\section{Adherence to International Human Rights Instruments}

Under each governance area, the country review reports set out the relevant international instruments that the state has ratified and those instruments with ratification still outstanding. ${ }^{79}$ Like most African countries, those under review have ratified most of the main international human rights treaties. However, there are some notable exceptions. For example, Rwanda has not ratified the Convention against Torture (CAT) and Kenya and Rwanda have not ratified the first Optional Protocol to the Covenant on Civil and Political Rights (ICCPR) allowing for individual complaints to the Human Rights Committee.

In its response to the report, the Kenyan government tried to explain why it has not ratified certain instruments. For example, the government states that because Kenya is a state party to the Convention on the Elimination of All Forms of Discrimination Against Women (CEDAW), it does not need to ratify the Protocol to the African Charter on Human and Peoples' Rights on the Rights of Women in Africa. ${ }^{80}$ In fact, the Protocol covers many rights not protected by CEDAW. As to why it has not ratified the optional protocol to CAT, the Kenyan government states that it "outlaws capital sentence." 81 In truth, the protocol in question does not mention the death penalty, but deals with preventative measures against torture, which is relevant for Kenya considering the concern expressed by the UN Human Rights Committee on the frequent use of torture in police custody in Kenya. ${ }^{82}$

The approach the Panel takes to domestication varies between the reports. The Rwanda Report recommends that the government "[a]dapt and harmonise its domestic laws to be consistent with international commitments, while giving due attention to its own realities." 83 The Ghana Report recommends that the country incorporate ratified conventions into domestic law. ${ }^{84}$ The Kenya Report does not explicitly suggest incorporation, but recommends that Parliament "pass all laws reflecting the international norms and standards acceded to by the Government soon after ratification." 85 


\section{2. $\quad$ State Reporting}

Each of the three country reports highlights insufficiencies of state reporting with respect to progress under international human rights instruments the country has ratified. The Rwanda Report notes that problems with regard to standards and codes include tardiness in reporting. The Ghana Report refers to inadequate reporting to the African Commission and recommends the adoption of a plan for reporting. ${ }^{86}$ The Kenya Report states that the country review mission "was unable to verify Kenya's adherence to reporting timelines under the relevant treaty monitoring bodies due to its inability to meet with the relevant government officials." ${ }^{27}$ This statement is surprising as information on state reporting is easily accessible. In its response to the report, the Kenyan government incorrectly asserted that the government is "up to date in reporting" under CRC, CEDAW, CAT, ICCPR and ICESCR.”,88

The lack of compliance with reporting obligations is unfortunate as increased reporting, subsequent concluding observations, and the use of these observations in various contexts, such as the APRM, could lead to a mutually reinforcing system for monitoring compliance with international norms. ${ }^{89}$ This would require that the persons involved in the ARPM process take note of the outcomes of the state reporting and communications procedures before the human rights monitoring bodies, ${ }^{90}$ and of the findings of the special procedures of the UN and the African Commission on Human and Peoples' Rights. ${ }^{91}$ The findings of national human rights institutions should also form part of this process. Very little evidence of such institutional reinforcement exists in the first three APRM reports.

\section{B. Assessment of APRM Objectives}

As discussed above, the APRM framework documents set out objectives under the four governance areas. ${ }^{92}$ These objectives help to structure the self-assessment report, the PoA and the country review report. However, overlap between the objectives also causes unnecessary duplication and sometimes contradictions within the reports.

\section{Democracy and Political Governance}

\section{a. $\quad$ Objective 1: Prevention of Conflicts}

Objective 1 under Democracy and Political Governance is the prevention and reduction of conflicts. The distribution of land is identified as a concern in all the reports. The Panel notes in the Kenya Report that the government should "adopt and implement redistribution and reallocation policies to enforce equitable access to, and use of land."93 The Panel calls on Ghana to implement proposals for a comprehensive land law "bearing in mind the needs of vulnerable groups, especially women." 94 The PoAs of both countries include measures to comply with these recommendations. The Rwandan self-assessment identifies "land as a very serious source of conflict." 95

The Panel recommended that the Kenya National Commission on Human Rights “check human rights transgressions of law enforcement officers" and sensitize citizens about their right to seek redress. It also requested law enforcement agencies to train their staff in human rights. ${ }^{96}$ In the PoA, civic education is included under Objective 1, while training of law enforcement officers and monitoring activities are included under Objective 3. 


\section{b. Objective 2: Enhancing Constitutional Democracy}

At least rhetorically, democracy and political participation play an important role on the African continent. Multi-party elections are now the rule on the continent, but democracy is much broader than elections. ${ }^{97}$ Under Objective 2, Enhancing Constitutional Democracy, concerns are expressed in the self-assessment and by the Panel about the institutional capacity of the Ghanaian electoral commission. ${ }^{98}$ These concerns are not reflected in the recommendations of the Panel or in the PoA. Concerns expressed in the self-assessment about low representation of women in decision-making positions, are partially reflected in recommendations on affirmative action in "organs of the decentralized system of governance."99 The Ghana self-assessment notes that access to justice is effectively denied to a large portion of the population because of poverty, ${ }^{100}$ but there is no mention of this in the Panel's recommendations. However, the PoA provides for "[i]ncreased capacity of legal sector to provide affordable and speedy access to justice." The report further notes that human rights education forms part of the curricula of training for the military and security forces in Ghana. ${ }^{101}$

With regard to Rwanda, the Panel notes the inadequacy of the country's self-assessment concerning this second objective and notes that "while the Rwandan Constitution guarantees freedom to form, join and belong to political parties, it simultaneously undermines that freedom by attaching onerous conditions, such as political parties not being able to operate at the grassroots below the provincial levels." ${ }^{102}$ It finds that "[p]olitical parties may be de jure authorised but de facto impossible to realise and operate freely." ${ }^{103}$ Surprisingly, these strong words on political participation are not reflected in the recommendations that deal with the electoral commission, decentralization, financial accountability, and measures to engage citizens and civil society in local government processes. ${ }^{104}$ The PoA does not set out any measures to implement the findings under this objective. ${ }^{105}$

Most African countries have a national human rights infrastructure. National human rights institutions exist in many African countries, including Ghana, Kenya and Rwanda. ${ }^{106}$ The National Commission for Civic Education and the Commission for Human Rights and Administrative Justice (CHRAJ) in Ghana are identified as best practices by the Panel. ${ }^{107}$ However, the Ghana self-assessment notes that the decisions of CHRAJ have not always been respected by the government. ${ }^{108}$

\section{c. Objective 3: Promotion and Protection of Human Rights}

Though human rights are dealt with throughout the reports, Objective 3 provides for the omnibus clause: "Promotion and protection of economic, social and cultural rights, civil and political rights as enshrined in African and international human rights instruments." 109 The reports are relatively brief on this objective. ${ }^{110}$

In its summary of the Ghana self-assessment, the report states that "[t]here was little evidence of direct human rights violations over the five-year period of 1999 to 2004."111 This indicates a very narrow definition of human rights. Seen from the perspective of violations of civil and political rights by the government, there is indeed ample evidence that the situation has improved. On socioeconomic rights, there are concerns that these rights are "virtually nonexistent" at least theoretically, be enforced by the courts. The comment seems to confuse the recognition of socioeconomic rights with their implementation. The Panel recommends the adoption of the 
Access to Information Bill, institutional reform of CHRAJ and policy clarification regarding the status of its decisions, adoption of a policy designed to enforce the international law of free and compulsory basic education, reform of the police and security services, adoption of a plan for ratification of international human rights treaties, implementation of state reporting obligations, domestication of applicable international human rights instruments, and release of the findings of the Reconciliation Commission. ${ }^{113}$ Many of the proposed actions in the PoA under this objective are unrelated to these recommendations and would fit better under other objectives. ${ }^{114}$ Some proposed actions overlap with actions proposed in other parts of the PoA.

Under Objective 3, the Rwanda Report discusses policies with regard to health and education that are further dealt with in the report under socioeconomic development. Decentralization of the health system is noted as a best practice. ${ }^{115}$ The Panel expresses some concern about press freedom, but the main focus is on the Rwanda Gacaca court system "as the most important vehicle for access to justice." 116 This might be true in the context of justice in the aftermath of the genocide, but access to justice is much broader than this. Surprisingly, the only recommendation by the Panel relates to the Gacaca system.

The respect for civil and political rights is highlighted as a best practice in the Kenya Report: "Political and civil rights are exercised with a considerable degree of freedom."117 This assertion goes contrary to the UN Human Rights Committee, which noted many deficiencies with regard to Kenya's implementation of the ICCPR, for example, impunity of law enforcement officers for extrajudicial killings ${ }^{118}$ and torture in police custody. ${ }^{119}$ As explained above, the Panel has taken note of the problem and made recommendations under Objective 1 . The analysis and recommendations under Objective 3 in the Kenya Report is mainly focused on socioeconomic rights. The Panel recommends that the government accord economic, social, and cultural rights "the necessary recognition and relevance." It further recommends the adoption of a universal health care plan and the HIV/AIDS Prevention and Control Bill. ${ }^{120}$ The PoA includes these measures under Objective 3 together with other human rights issues that have been raised by the Panel under other objectives.

\section{d. Objective 4: Separation of Powers}

Objective 4 deals with the separation of powers, including the independence of the judiciary. The fusion of powers in the executive in Rwanda is seen as a "recipe for danger." ${ }^{\text {"121 }}$ The Panel makes several recommendations to ensure the independence of the judiciary and to strengthen the Bar Association. ${ }^{122}$ None of these recommendations are reflected in the PoA.

With regard to Kenya, the Panel recommends performance based contracts for the judiciary to improve efficiency and accountability. ${ }^{123}$ The PoA sets aside US\$300,000 to address the backlog of court cases, but does not set out how the money will be used. ${ }^{124}$ Apart from these recommendations, the report under Objective 4 only addresses issues of reforms of Parliament, even though glaring problems with regard to the independence of the judiciary are raised in the report.

The Panel recommends that Ghana creates new courts of appeal to ease congestion and to take measures to reduce the back log of cases. ${ }^{125}$ The latter recommendation is taken up in the PoA, though it is unclear which measures will be adopted to achieve the goal.

\section{e. $\quad$ Objective 5 and Objective 6}


Objective 5, to "ensure accountable, efficient and effective public office holders and civil servants," is linked to Objective 6 on fighting corruption in the political sphere. Anti-corruption measures are also dealt with in the chapters on economic governance. Objective 5 also deals with service delivery, which also falls under Objective 4 under socioeconomic development.

\section{f. $\quad$ Objective 7: Promotion and Protection of the Rights of Women}

Objectives 7 deal with promotion and protection of the rights of women. The Rwanda Report observes that the country has made great strides with regard to gender equality. That women have 49 percent of the seats in the Rwandan Chamber of Deputies is regarded as a best practice. However, the Panel notes that capacity building is needed and that despite actions taken against societal discrimination against women, there is still much to do. ${ }^{126}$ The Panel's recommendations are limited to capacity-building for parliamentarians and continued implementation of laws and policies.

With regard to the review of Ghana, the Panel recommends the ratification of the Protocol to the African Charter on the Rights to Women in Africa, the adoption of the Domestic Violence Bill and other measures against violence against women, increased budgetary allocation for institutions involved in protecting the rights of women, domestication of CEDAW, and the adoption of a 40 percent quota for women in public offices. ${ }^{127}$ Most of these recommendations are reflected in the PoA. Policies to increase the number of women in politics should be developed, but no percentage quota is given. It is not clear from the report what has stood in the way for implementation of the Affirmative Action Policy of 1998, which is mentioned in the self-assessment. ${ }^{128}$

The Kenyan report provides a poignant analysis of the discrimination against women in Kenyan society. The Panel recommends that the government adopts an affirmative action plan "to address the structural challenges and imbalances faced by women at diverse levels in the political, civil, economic, social and cultural spheres."129 In line with recommendations of the Panel, the PoA also includes the adoption of the Domestic Violence Bill, civic education on women's rights, and the amendment of inheritance laws.

\section{g. Objective 8: Rights of Children and Youth}

Objective 8 deals with the rights of children and youth. Child trafficking and child labor are serious problems in Kenya and the Panel recommends that the government develops a timebound national action plan to address these issues. The PoA takes a wider approach and provides for an action plan to combat violations of children's rights. ${ }^{130}$ The PoA also includes measures against rape, female genital mutilation, and early marriages.

The Panel's recommendations in the Rwanda Report are not very clear. A provision on reintegration of children is possibly referring to former child soldiers. The Panel further recommends that Rwanda "[w]ithdraws reservation on compulsory education and criminalises the act of not sending children to schools." ${ }^{131}$ It is not clear which reservation it refers to, and it is questionable whether criminalization is a good way to increase school attendance. The PoA provides for a study to review the rights of children and youth and the enactment of laws and establishment of institutions to "ensure children's rights and welfare."132

The recommendations in the Ghana Report focus on the ratification of international instruments and further recommend that the Ghana National Commission on Children is given 
more autonomy and that budgetary allocation to institutions dealing with children's rights are increased. $^{133}$

h. $\quad$ Objective 9: Rights of Vulnerable Groups

Objective 9 relates to the rights of vulnerable groups, including internally displaced persons and refugees. The Ghana self-assessment defines vulnerable groups as "ethnic minorities, refugees, migrant workers, the aged, disabled persons, people with HIV/Aids and children orphaned by HIV/Aids." "34 The Panel's only recommendations are that the international community should assist Ghana in dealing with the refugee situation and that Ghana reviews its capacity to cater to internally displaced persons. Both recommendations seem a bit out of place as they are not based on any analysis in the report. ${ }^{135}$ As a result, the recommendations are disregarded in the PoA, which instead provides for measures to ensure access to public facilities for the disabled, revision of the pension scheme, provision of a national policy on the aged, and a review of the Ghana Refugee Board.

The Panel recommends that Rwanda "step up efforts to provide education, health and housing for displaced persons and/or refugees" and "initiate an in-depth dialogue with the Batwa."136 The Panel's contention that the authorities aim for the assimilation of the Batwa minority, ${ }^{137}$ was strongly contested by the government in its response to the report.

\section{Economic Governance}

NEPAD has been criticized for entrenching a neoliberal economic policy. ${ }^{138}$ While there is no explicit discussion of human rights in the objectives under Economic Governance, economic policies clearly have an impact on the enjoyment of human rights. This impact is to a limited extent recognized in the country review reports.

\section{a. Objective 1: Promote policies that support sustainable development}

Objective 1 is to "promote macroeconomic policies that support sustainable development." Fortunately, the country review reports recognize the problem of increasing poverty levels despite economic growth. ${ }^{139}$ Three main issues are identified in the Kenya Report: diversification of domestic production and exports, the availability of credit, and nonimplementation of policy measures in the public sector. ${ }^{140}$

The economic policies of most African states are heavily influenced by the international financial institutions, in particular the International Monetary Fund (IMF). Poverty reduction strategy papers (PRSPs) are produced as a prerequisite for debt relief for highly indebted countries. Their aim is to "promote broad-based growth and reduce poverty" through a "participatory process involving domestic stakeholders." 141 Of the twenty-seven countries that have signed up for the APRM, only seven do not participate in the PRSP process. ${ }^{142}$ However, the PRSP process is not as comprehensive as the APRM, in particular with regard to issues of democracy, political governance, and human rights. The Kenya review report notes with some surprise that there was no discussion in Kenya's self-assessment of country ownership of economic policy and reforms. ${ }^{143}$ The Ghana Report discusses the importance of national ownership but manages to do so without mentioning the international financial institutions. ${ }^{144}$ Weak civil society participation in economic policy making is identified with respect to both 
Ghana and Kenya. ${ }^{145}$

The Rwanda Report includes a recommendation to the government to continue with the "redrafting of the second PRSP strategy and the restructuring of economic priorities from social spending to productive activities." 146 This is despite the same report noting the importance of social spending on, for example, education and health. ${ }^{147}$

\section{b. $\quad$ Objective 2: Transparent Government Economic Policies}

Objective 2, "implement transparent, predictable and credible government economic policies," overlaps to some extent with Objective 1. Transparency is obviously important with regard to all government policies, not only those dealing with economic management. On Ghana, the Panel's recommendations include that all ministries, departments, and agencies covered by the selfassessment shall conduct and publish their own self-assessment, with an action plan to address identified shortcomings. ${ }^{148}$

c. Objective 4: Fight corruption and money laundering

Corruption is a cross-cutting issue. Thus, the fight against corruption is included under economic governance in addition to the democratic and political governance area. ${ }^{149}$ The Rwanda Report illustrates state responsibility for acts abroad in discussing the issue of plunder of natural resources in the DRC and recommends that the authorities "[c]larify, in the most transparent way, the conduct of Rwandan troops and security operatives in the DRC to bring satisfactory closure to this matter together with the UN and the DRC.”"150

\section{d. Objective 5: Regional integration}

Regional integration is set out as an objective of the APRM. ${ }^{151}$ The questions and indicators listed in the Questionnaire are focused solely on the positive aspects of economic integration. However, possible negative consequences are considered to some extent in the country review reports. ${ }^{152}$

\section{Corporate Governance}

The chapters on corporate governance deal with human rights issues such as workers rights under Objective 2 which is to "ensure that corporations act as good corporate citizens with regards to human rights, social responsibility and environmental sustainability.” The Rwanda Report focuses almost exclusively on environmental issues under this objective. ${ }^{153}$ The Ghana Report devotes one page to the issue in which it manages to deal with low wages, discrimination against women, child labor, and the environment. Not much of this is reflected in the quite extensive recommendations that also overlap with objectives in other governance areas. For example, child labor is dealt with both under Objective 2 of corporate governance and under children's rights in the chapter on political governance. The Kenya Report is the most elaborate on this objective, considering labor rights, corporate social responsibility, the environment, gender, and youth. ${ }^{154}$

\section{Socioeconomic Development}

Under socioeconomic development, the reports rely on PRSPs, national development strategies, 
and Millennium Development Goals (MDGs). Objective 2 essentially restates the overarching objective of NEPAD and the whole APRM process: "Accelerate socioeconomic development to achieve sustainable development and poverty reduction." As has been noted above, the achievement of sustainable development is also included as an objective under economic governance. This leads to unnecessary duplication.

\section{a. $\quad$ Objective 3: Strengthen Social-Development}

In accordance with Objective 3, countries are to "strengthen policies, delivery mechanisms and outcomes in key social-development areas (including education and combating of HIV/AIDS and other communicable diseases).”

The right to free and compulsory basic education is guaranteed in the Ghanaian constitution. However, the Panel notes that "several stakeholders across the country in the regions visited complained about the high cost of education, including basic education, which renders education unavailable to many." ${ }^{155}$ Concern about deteriorating quality was also raised. ${ }^{156}$ The report further explained the sharp increase in public expenditure on education in recent years, but acknowledged that "although many schools have been built in the last few years, this development has not been matched by the recruitment of sufficient numbers of teachers. ${ }^{157}$ It is unlikely that Ghana will meet the MDG on education. ${ }^{158}$ The report takes note of the 1995-2005 strategic plan for Free Compulsory Universal Basic Education, but does not evaluate why the country has not achieved its goal. ${ }^{159}$ The Panel recommended that the government "[a]dopt a policy designed to enforce the international law of free and compulsory basic education." "160 The PoA sets out actions costing US\$ 82 million for the period 2005-2015 in order to achieve "progress towards full enrolment." The problem with the quality of education is addressed in the PoA by providing for the training of more teachers and higher teacher wages. ${ }^{161}$ The Ghana Report does not discuss health issues under Objective 3, though the recommendations include the creation of incentives for health professionals to work in rural areas and the north.

The Rwanda Report focuses its discussion under Objective 3 on health. It informs that the latest statistics indicate an increase in the number of physicians and nurses ${ }^{162}$ The Panel found the decentralization efforts with regard to health care to be a best practice. ${ }^{163}$ Despite this, there was no improvement in outcome indicators such as child and maternal mortality and malaria and HIV prevalence. ${ }^{164}$ However, the PoA provides for substantial resources to be set aside for access to obstetric services to decrease the maternal mortality rate. ${ }^{165}$ A community based health insurance scheme has been established. ${ }^{166}$ There are plans to set the membership fee at 1000 Rwanda francs (US\$2) nationally. ${ }^{167}$ This health insurance plan was endorsed by the Panel. ${ }^{168}$ While increased enrollment in the scheme is beneficial, the report does not address those who cannot afford the membership fee or procedures not covered by the insurance plan ${ }^{169}$ The Panel recommends the building of more schools to increase enrollment, without discussing the need to increase the number of teachers.

\section{b. Objective 4: Affordable Access to Services}

To live in dignity includes having access to basic services such as safe water, sanitation, and shelter. Objective 4 under socioeconomic development is entitled "Ensuring affordable access to water, sanitation, energy, finance (including micro-finance), markets, ICT [information and 
communication technology] [and land] to all citizens, especially the rural poor." ${ }^{\prime 70}$ Delivery of basic services is identified as a major problem in all three countries. The Panel states in the Ghana Report that "[w]hat is needed is for the authorities to have clear plans of action for each service, involving targets and objectives, policies and measures for achieving them, and a feasible time-frame." ${ }^{\text {"171 }}$ Even though capacity constraints exist, political will is deemed the most important factor, in particular with regard to inadequate service delivery in the north. ${ }^{172}$ The Ghana PoA sets out various actions to address accessibility to the services set out above. The estimated cost for these measures is more than US\$ 1 billion. In its recommendation on Kenya, the Panel only addresses market information to farmers, energy sector reform, access to ICT, and the development of a comprehensive housing strategy. ${ }^{173}$ However, the PoA also addresses access to safe water and measures to ensure water for irrigation and to control floods. Total spending under this objective in the Kenya PoA is less than US\$ 55 million. The recommendations by the Panel to the Rwandan government include maintaining "its impetus to ensure that access to basic amenities is not restricted to the urban areas" and "continue to research alternative means of livelihood to alleviate the land issue.”" ${ }^{\prime 74}$ The Rwandan PoA mainly focuses on the development of new policies.

\section{c. $\quad$ Objective 5 and Objective 6}

Objective 5 on gender mainstreaming and equality clearly overlaps with the objective on women's rights under political governance. Objective 6 deals with broad-based participation in development. The Panel recommendations under this objective in the Ghana Report deal with regional inequalities. The recommendations in the Kenya Report focus on local input in project planning and implementation and the participation of civil society in the preparation of the national budget. ${ }^{175}$

\section{Overarching Issues}

The concluding chapters in the country review reports set out overarching issues of concern and follow-up measures. The Ghana Report sets out capacity constraints, gender, corruption, decentralization, the land issue, chieftaincy, unemployment, and external dependency as overarching issues. The Rwanda Report identifies land and population, political pluralism and competition of ideas, Gacaca courts, capacity constraints, aid effectiveness, and the managing of diversity. The Kenya Report identifies managing diversity in nation building, implementation gaps, poverty and wealth distribution, land, corruption, the Constitution, gender inequality, youth unemployment, and lack of transformative leadership.

In addition to overarching issues and a discussion of follow-up measures, the Ghana and Kenya Reports also include a short discussion of the PoA as submitted by the country after it has taken note of the Panel's recommendations. The Kenya Report notes that "Kenya has presented clear, time-bound commitments on key governance and socioeconomic development priorities over the next three years, including the identification of key stakeholders for implementation, and the estimated budgetary implications."176 This important discussion is absent from the Rwanda Report.

VII. Conclusions 
A weak feature in all of the reports is an often missing link between the analysis in the report, the recommendations, and the PoA. The Panel, Secretariat, and members of country review missions should ensure that recommendations reflect the concerns expressed and are presented in a structured manner. The Panel should assist in framing the issues in the PoA, but a state should also be able to approach an issue differently than suggested by the Panel, as long as it explains the motivation behind the divergent approach. Kenya provides a good example in responding to most recommendations and explaining why certain recommendations are not taken on board. Rwanda's PoA, on the other hand, is to a large extent not linked to the recommendations, or indeed to any analysis in the report. To varying degrees the reports and PoAs also display a lack of consistency; an issue might be dealt with in the report under one objective, a recommendation by the Panel is considered on the issue under a second objective, while the PoA lists actions to be taken under a third objective. The Panel should address this inconsistency and also ensure consistency between the reports. Ideally, to allow for easy comparison, the same issues should be dealt with under the same objective.

It is essential that the PoA becomes an integrated program for change and not an à la carte wish list. The total estimated cost for implementing the programs are US\$ 95 million for Rwanda, ${ }^{177}$ US\$ 5 billion for Ghana, ${ }^{178}$ and US\$ 5.3 billion for Kenya. In one of the framework documents of the APRM, the Panel pointed out that the PoA must be realistic. ${ }^{179}$ In its Kenya Report, the Panel noted that "policies are usually unfunded in the National Planning process. Parliament or the Executive enacts laws without securing funding for their implementation.”180 The Panel recommended that the government "align the enactment of laws, policies and programmes with adequate and sustained funding so as to secure implementation." "181 While it is clear that funding will not have been secured for everything in the PoA at the time of its adoption, the PoA should at least indicate for which projects there is existing funding and for which external funding is sought. The Ghana and Kenya programs might be overly optimistic when it comes to how much financial resources can be mobilized to implement the programs. The main responsibility in devising a realistic PoA lies with the national APRM process. Recommendations by the Panel on priorities in the PoA could be helpful both for the country under review and for international donors. ${ }^{182}$

Accuracy is very important in a process of this nature. Unfortunately, self-assessments, country review report findings, Panel recommendations, and government responses include sweeping statements that, on close scrutiny, sometimes turn out to be questionable and occasionally wrong. ${ }^{183}$ One often heard criticism is that the review process takes too long. ${ }^{184}$ At the same time it is clear that some of the timelines in the process are very tight, such as the writing of the country review report after completion of the country mission. As is clear from the analysis above, this negatively affects the quality of the reports. Expediency should never be given precedence over the quality of the review. The various stages of the process should be analyzed to see in what ways the review process can be made more efficient. In particular, adequate time must be given to develop a proper PoA with the involvement of all stakeholders.

Human rights issues have been addressed to some extent in the country review reports. However, the lack of a human rights focus in the self-assessment could influence a lack of such a focus in the country review report as exemplified by the Rwanda Report. This lack of human rights perspective follows from the emphasis on self-assessment in the APRM process. However, it should be noted that the Panel did not hesitate to discuss some pertinent human rights issues with regard to Rwanda, such as political participation, despite their omission from the selfassessment. 
Improvements in approach would include a greater reliance on human rights standards and principles in devising proposed actions to deal with identified problems. International human rights norms could also be relied on in defining the indicators to measure progress in the PoA. In dealing with human rights, there is no reliance on the findings of international human rights monitoring bodies. The Panel has pointed out that the participating countries should ensure consistency between the APRM and other initiatives, including national human rights action plans. ${ }^{185}$ Thus, it is surprising that no reference is made to the non-existence of such plans in the reports. ${ }^{186}$ It should also be noted that the APRM process both in its analysis and in actions to remedy deficiencies relies heavily on formal institutions. Not much attention is given to the important role that informal institutions play in Africa. ${ }^{187}$

The APRM framework documents identify participation as an important factor in achieving the goals of the process. For effective participation, there is a need of a free and strong national civil society. The review in Rwanda illustrates how the state easily takes control over the process when there is not effective participation. Unfortunately, there are many other countries among those which have signed up for the APRM lacking strong civil society and will therefore be unlikely to give existing organizations any real say in the process.

Despite the deficiencies identified in this article, there are reasons not to be too pessimistic about the process. Many of the shortcomings in the reports can be traced back to time constraints, a shortage of staff at the APRM Secretariat, and to an inadequately structured Questionnaire. Positive outcomes from the first reviews include no sign in the reports of deference to governments from the side of the Panel, despite concerns that some Panel members are too strongly connected to government. Many commentators have doubted that African leaders will criticize each other. In their view, there can be no effective peer review. Nonetheless, the fact that African heads of state and government are participating actively in the process is a big step forward in diminishing the non-interference rule that has characterized African regional cooperation since independence.

The problems with the APRM as a mechanism to ensure compliance through peer pressure by African leaders should also not detract from features that could prove more successful. Seemingly, the APRM process has received more attention than the procedures and outcomes of other monitoring mechanisms. This attention can be turned to public pressure to realize the priorities set out in the report and PoA. The role of the APRM to illustrate best practices from other countries could also be potentially beneficial. However, the best practices identified by the Panel should be concrete and exportable.

To achieve progress in human rights protection in Africa, many different strands must come together to form a strong rope. ${ }^{188}$ Properly implemented, the APRM can be one strand in the thick rope needed to drag the continent out of poverty and violations of human rights. Judicial protection at the national and international level and pressure from national stakeholders are other strands in this rope. Identifying the shortfalls is seldom the problem. Finding the solutions is often much more difficult.

To a much larger degree, the APRM process should build on existing monitoring, both national and international, and should reinforce it instead of diffusing these efforts. More emphasis must be put on the process of devising a proper Program of Action integrated with existing initiatives. This would help the APRM to make the best use of one of its prime features, its holistic approach to development. Many international treaties, both regional and global, deal with issues that fall under the APRM mandate. It is suggested that these instruments should not only be considered under the heading implementation of standards and codes, but that in 
particular, African regional instruments should be clearly reflected in the questions and indicators devised. In cases where there are already oversight mechanisms in place to monitor the implementation of these instruments, such as the African Commission on Human and Peoples' Rights and the African Committee on the Rights and Welfare of the Child, the relevant sections of the Questionnaire should be devised in close cooperation with these institutions. ${ }^{189}$

The APRM process can be seen as a developed version of the state reporting system that exists under, for example, the African Charter on Human and Peoples' Rights. ${ }^{190}$ It is suggested that the APRM process can replace state reporting to the African Commission on Human and Peoples’ Rights for countries which participate in the APRM. ${ }^{191}$ However, this would require more active participation of the Commission in the APRM process. Such participation is foreseen in the APRM framework documents, but has not been implemented in practice. It is suggested that at least one member of the Commission, assisted by a staff member, should participate in each country review mission. Furthermore, the tabling of the APRM report before the Commission must be taken seriously. This could be done by the Commission member that participated in the country review mission acting as rapporteur on the report. The report, in relevant parts, should then be examined by the Commission in the procedure that applies to examination of state reports, with questions being posed by all of the Commissioners. As is the case with the examination of state reports, a high-level government delegation should be present to respond to questions. The Commission should issue concluding observations setting out any recommendations or comments on issues that they think have not been properly addressed in the report or the PoA. These concluding observations should be sent to the government, NGOs that participated in the review process, the national governing council, and the APRM Secretariat in South Africa, thus feeding into the on-going review process.

The suggested process would require re-thinking the basic framework for the review, in particular, OSCI and the Questionnaire. There is general agreement that the Questionnaire must be reviewed because it is too complicated and creates too much duplication. Ideally, the structure of the review would be divided into two governance areas rather than four. Democracy and political governance could be expanded to include most of the objectives under socioeconomic development. In addition, it could include Objective 4 under economic governance, dealing with corruption as well as Objective 2 under corporate governance, dealing with corporate responsibility. The number of objectives should be reduced and should not address the same issue under more than one objective. A review of the questions and indicators under the objectives is needed. It is clear from the reports that these have not given sufficient guidance to stakeholders in the participating country, the APRM Secretariat, and country review consultants.

Civil society and national APRM structures play an important role in ensuring that the Programs of Action are implemented. The APRM Secretariat, Panel, and Forum also play a role in ensuring follow-up.

Ghana, Rwanda and Kenya have already presented their first reports on implementation of the PoAs to the Forum. However, many countries are still in the early stages of the process and have not yet started with their self-assessment. The cost of the review process might be one factor contributing to the slow take off. ${ }^{192}$ The enthusiasm for the APRM might also decline in the face of the frank criticism expressed in the country review reports on Ghana, Kenya, and Rwanda.

Time will tell whether the APRM will count as a success story or whether it will slowly starve to death by inaction as so many initiatives of the past. The outcome will be determined by the political will of leaders in Africa and elsewhere in the world. 
Endnotes

* Magnus Killander is a researcher and LLD candidate at the Centre for Human Rights, University of Pretoria, South Africa, www.chr.up.ac.za. He is co-editor of the African Human Rights Law Reports and the Compendium of Key Human Rights Documents of the African Union, and associate editor of International Law in Domestic Courts. He holds the degrees jur kand (Lund) and EMA (Padua). Thanks to Christof Heyns, Michelo Hansungule and Frans Viljoen for comments on an earlier draft.

1 African Peer Review Mechanism, Country Review Report of the Republic of Kenya 29 ( 2006), available at http://www.nepad.org/2005/files/aprm/APRMKenyareport.pdf [hereinafter KENYA REPORT]. The report as published on the web is the final version even though it is written at the bottom of the pages of the report that it is a 'confidential working document'.

2 See, e.g., IAN TAYLOR, NEPAD: TOWARD AFRICA's DEVELOPMENT OR ANOTHER FALSE START? 63 (2005) [hereinafter TAYLOR].

3 At the time of writing, September 2007, APRM country review reports had only been completed on five of the twenty-seven participating countries. The country review reports of Ghana, Kenya, and Rwanda were all published during 2006. The reports on Algeria and South Africa had as of September 2007 not yet been officially published.

4 For an overview of the institutional framework for human rights under the African Union see Christof Heyns \& Magnus Killander, The African Regional Human Rights System, in InTERnAtional PROTECTION OF HuMAN Rights: ACHIEVEMENTS AND CHALLENGES (Felipe Gómez Isa \& Koen de Feyter eds., 2006).

5 The New Partnership for Africa's Development, (NEPAD), available at www.nepad.org [hereinafter NEPAD Framework Document]. At its adoption the NEPAD was known as the New African Initiative (NAI), see Declaration on the New Common Initiative, AHG/Decl.1 (XXXVII), 2001 (Lusaka). The name was changed to the New Partnership for Africa's Development at the first meeting of the Implementation Committee in October 2001. On the origins of NEPAD see TAYLOR, supra note 2. In 2002 the OAU was replaced by the African Union (AU).

6 Ross Herbert, NEPAD, and the many challenges of Africa, in SOUTH AFRICA 2014: THE STORY OF OUR Future (Guy Lundy, Steuart Pennington \& Brett Bowes eds., 2004).

7 NEPAD Framework Document, supra note 5, ๆ 26.

8 Declaration on Democracy, Political, Economic and Corporate Governance (Declaration on Democracy and Governance), AHG/235 (XXXVIII) Annex 1, art. 7. This Declaration, adopted by the NEPAD Implementation Committee in June 2007, was endorsed by the AU Assembly in July 2002, Declaration on the Implementation of the New Partnership for Africa's Development (NEPAD), ASS/AU/Decl.1 (I).. 
9 African Peer Review Mechanism (APRM): Base Document, NEPAD/HSGIC/032003/APRM/MOU/Annex II, adopted at the 6th Summit of the NEPAD Heads of State and Government Implementation Committee, 9 Mar. 2003, Abuja, Nigeria, (2003).

10 G8 Africa Action Plan 97 (2002).

11 See, e.g., Africa/OECD Ministerial Consultation Big Table II, Amsterdam, 14-16 October 2001, Summary Report, available at http://www.uneca.org/eca_resources/major_eca_websites/TheBigTable/bigtable2.htm. On OECD peer review see Fabrizio Pagani, Peer Review: A Tool for Co-operation and Change-An Analysis of an OECD Working Method (OECD, 11 Sept. 2002).

12 See e.g., Open method of co-ordination (OMC), see Armin Schäfer, A New Form of Governance? Comparing the Open Method of Co-ordination to Multilateral Surveillance by the IMF and the OECD 13 J. EUR. PUB. POLICY 70 (2006).

13 WTO Trade Policy Review Mechanism.

14 For a comparison of some of these reviews with the APRM see Zein Kebonang, African Peer Review Mechanism: An Assessment, 61 IndiA Q. 138 (2005).

15 Declaration on the Implementation of the New Partnership for Africa's Development, ASS/AU/Dec. 1(I) I 12, available at http://au2002.gov.za/docs/summit_council/audecis1.htm\#decl2.

16 Communiqué issued at the end of the fifth summit of the Heads of State and Government Implementation Committee (HSIC) of the New Partnership for Africa's Development, Abuja, (Sunday, 03 November, 2002) I 20 [hereinafter Communiqué]

17 Communiqué, supra note 16, \19.

18 Communiqué, supra note 16, ๆ 14.

19 State of the nation address of the President of South Africa, Thabo Mbeki, Houses of Parliament, Cape Town (14 Feb. 2003), available at http://www.info.gov.za/speeches/2003/03021412521001.htm. Plans for obligatory peer review under the Conference on Security, Stability, Development and Cooperation in Africa (CSSDCA) were developed in 2002, but this process has not been implemented and the CSSDCA unit in the AU Commission has been transformed to the African Citizens' Directorate (CIDO) dealing with the relationship with civil society organizations. AFRIMAP, AFRODAD \& OXFAM, TOWARDS A People-Driven African Union - CurRent Obstacles \& New Opportunities 29 (2007). On the planned CSSDCA process, see Bronwen Manby, The African Union, NEPAD, and Human Rights: The Missing Agenda, 26 HuM. RTs. Q. 983, 992-94 (2004) [hereinafter Manby].

20 Communiqué issued at the end of the Sixth Summit of the Heads of State and Government Implementation Committee (HSGIC) of the New Partnership for Africa's Development, 9 Mar. 2003, I 24. Memorandum of Understanding on the African Peer Review Mechanism (APRM 
MOU), 9 Mar. 2003, NEPAD/HSGIC/03-2003/APRM/MOU.

21 Communiqué, supra note 20, 凤 24.

22 Algeria, Angola, Benin, Burkina Faso, Cameroon, Congo-Brazzaville, Djibouti, Egypt, Ethiopia, Gabon, Ghana, Kenya, Lesotho, Malawi, Mali, Mauritius, Mozambique, Nigeria, Rwanda, São Tomé and Principe, Senegal, Sierra Leone, South Africa, Sudan, Tanzania, Uganda, and Zambia.

23 See, e.g., TAYLOR, supra note 2, at 68.

24 Objectives, Standards, Criteria, and Indicators For the African Peer Review Mechanism, Adopted at the 6th Summit of the NEPAD Heads of State and Government Implementation Committee, 9 March 2003, Abuja, Nigeria, NEPAD/HSGIC/03-2003/APRM/Guidelines/OSCI.

25 Prevention and reduction of intra- and inter-state conflicts; Constitutional democracy, including periodic political competition and opportunity for choice, the rule of law, citizen rights, and supremacy of the Constitution; Promotion and protection of economic, social and cultural rights, civil and political rights as enshrined in African and international human rights instruments; Uphold the separation of powers, including the protection of the independence of the judiciary and of an effective legislature; Ensure accountable, efficient and effective public office holders and civil servants; Fight corruption in the political sphere; Promotion and protection of the rights of women; Promotion and protection of the rights of children and young persons; Promotion and protection of the rights of vulnerable groups including internally displaced persons and refugees. It should be noted that some of the APRM documents, such as the Questionnaire, refer to "good political governance” instead of simply "political governance.”

26 Promote macroeconomic policies to support sustainable development; Implement sound, transparent and predictable government economic policies; Promote sound public finance management; Fight corruption and money laundering; Accelerate regional integration by participating in the harmonization of monetary, trade and investment policies.

27 Promote an enabling environment and effective regulatory framework for economic activities; Ensure that corporations act as good corporate citizens with regard to human rights, social responsibility and environmental sustainability; Promote adoption of codes of good business ethics in achieving the objectives of the corporation; Ensure that corporations treat all their stakeholders (shareholders, employees, communities, suppliers and customers) in a fair and just manner; Provide for accountability of corporations, directors and officers.

28 Promote self-reliance in development and build capacity for self-sustaining development; Accelerate socioeconomic development to achieve sustainable development and poverty eradication; Strengthen policies, delivery mechanisms and outcomes in key social areas including education and combating of HIV/AIDS and other communicable diseases; Ensure affordable access to water, sanitation, energy, finance (including micro-finance), markets, ICT, shelter and land for all citizens, especially the rural poor; Progress towards gender equality in all critical areas of concern, including equal access to education for girls at all levels; Encourage 
broad-based participation in development by all stakeholders at all levels.

29 The official title of the eighty-eight-page Questionnaire is Country Self-Assessment for the African Peer Review Mechanism [hereinafter Questionnaire]. At its February 2004 meeting the Forum requested that the Questionnaire should be sent to all participating countries as soon as possible. See Communiqué issued at the end of the First Summit of the committee of participating heads of state and government in the African Peer Review Mechanism (APR Forum) Kigali, Rwanda, 13 Feb. 2004, ๆ 21 [hereinafter Communiqué issued at the APR Forum].

30 See, e.g., SOUTH AFRICAN INSTITUTE OF INTERNATIONAL AFFAIRS, APRM LESSONS LEARNED, REPORT ON THE SAIIA CONFERENCE For CiVIL SOCIETy, PrACTITIONERS AND RESEARCHERs, 1012 (2006),[hereinafter, APRM LESSONS LEARNED], IMPLEMENTING THE AFRICAN PEER REVIEW MECHANISM - CHALlENGES AND OpPORTUNITIES, REPORT OF THE SiXTH AFRICA GOVERNANCE ForUM (AGF-VI), KigALI, RWANDA, 9-11 May 2006 (2006). The APRM Secretariat has indicated that a review of the APRM base documents, including the Questionnaire, is planned, see The African Peer Review Mechanism (APRM): Africa's Innovative Thinking on Governance, 3, (2007).

31 The institutions listed in the footnotes that follow are examples of some of the main international institutions involved in monitoring of compliance with international commitments, both soft law and hard law.

32 AU Peace and Security Council, UN Security Council (including sanction committees and the counter-terrorism committee).

33 The AU and sub-regional organizations often sends electoral observation missions to member countries. In addition overseas countries and organizations such as the EU often send missions to African elections.

34 African Commission on Human and Peoples’ Rights, African Court on Human and Peoples’ Rights, Pan-African Parliament, courts of sub-regional organizations, UN Human Rights Council and treaty bodies, World Bank Inspection Panel.

35 IMF article IV consultations, Poverty Reduction Strategy Papers (PRSPs).

36 The AU Convention on Preventing and Combating Corruption entered into force in August 2006. It provides for the establishment of an Advisory Board on Corruption. UN initiatives include the UN Convention against Corruption and the Global Program against Corruption of the Centre for International Crime Prevention.

37 South Africa is the only African member of the Financial Action Task Force on MoneyLaundering (FATF), but FATF-style sub-regional bodies have been established: the Eastern and Southern Africa Anti-Money Laundering Group (ESAAMLG) and the Inter-Governmental Action Group Against Money-Laundering in Africa (GIABA).

38 International Labor Organization (ILO) available at http://www.ilo.org/global.lang-- 
en/index.htm

39 World Bank Inspection Panel and various institutions established under international environmental law treaties available at http://web.worldbank.org

40 WTO Trade Policy Review Mechanism available at http://www.wto.org/English/tratop_e/tpr_e.htm

41 Reports on implementation of the Millennium Development Goals (MDGs), the annual UNDP Human Development Report, available at http://hdr.undp.org/, and World Bank World Development Report, available at www.worldbank.org/wdr/

42 Guidelines for Countries to Prepare for and to Participate in the African Peer Review Mechanism (APRM), NEPAD/APRM/Panel3/guidelines/11-2003/Doc8, adopted by the Panel Nov. 2003, ๆ 37, [hereinafter Guidelines].

\section{African PeER ReView Mechanism (APRM): APRM Base Document,} NEPAD/HSGIC/03-2003/APRM/MOU/Annex II, adopted at the 6th Summit of the NEPAD Heads of State and Government Implementation Committee, 9 Mar. 2003, Abuja, Nigeria, I 1825 (2003).

44 Guidelines, supra note 42. See also civil society initiatives such as THE SOUTH AFRICAN Insitute of International AfFAirs, Planning AN EFFECTIVE PEER REVIEW - A GuideboOK FOR NATIONAL FOCAL POINTS (2007).

45 Communiqué issued at the APR Forum, supra note 29, ๆף 24-25.

46 Guidelines, supra note 42, ๆ 18 (v).

47 See, e.g., APRM LESSONS LEARNED, supra note 30, at 4-6.

48 African PeEr Review Mechanism, Country ReView Report of the Republic of GhanA xi (2005), available at www.nepad.org/2005/files/aprm.php. [hereinafter GHANA REPORT] The same report but with slightly different pagination has been posted on other web sites including the Government of Ghana. References to the Ghana Report is therefore given to chapters/paragraph numbers, which seemingly are the same in all versions.

49 Ghana Centre for Democratic Development (democracy and political governance) available at www.cddghana.org; Centre for Policy Analysis (economic governance) available at www.cepa.org.gh; Private Enterprise Foundation (corporate governance) available at www.pefghana.org; and Institute of Statistical, Social and Economic Research (socioeconomic development) available at www.isser.org.

50 Francine Rutazana, Evaluation du processus du mécanisme africain de revision par les pairs au Rwanda (MAEP): Présentation à la rencontre de Banjul du 26 au 28 juin 2006 at 5 available at www.saiia.org.za. 
51 Id. at 6-7.

52 African Centre for Economic Growth (democracy and political governance), Kenya Institute of Public Policy Research and Analysis (economic governance), Centre for Corporate Governance (corporate governance), Institute for Development Studies, University of Nairobi (socioeconomic development).

53 KENYA REPORT, supra note 1, at 38.

54 Information on the early stages of the South African APRM process is available at http://www.aprm.org.za.

55 Ross Herbert, SA's Peer Review Tactics Dishonest, CAPE Argus, 20 May 2007. See also Ross Herbert, Mismanaged From the Start?, THE STAR, 25 Jan. 2007, available at http://www.saiia.org.za.

56 Rapport du MAEP, l'Algérie est sur la bonne voie, LA TRIBUNE (Algerie), 3 July 2007; M. Messahel: Le rapport d'évaluation sur la gouvernance en Algérie est l'un des "plus transparents,” Ministère des Affaires Etrangères, 16 July 2007, available at http://193.194.78.233/ma_fr/stories.php?story=07/07/15/0443837

57 Communiqué conjoint à l'issue de la mission de soutien du mécanisme africain d'évaluation par les pairs (MAEP) au Bénin, 14-17 Nov. 2005 available at www.nepad.org/2005/files/aprm/CommuniqueFinal-v2.pdf.

58 Guidelines, supra note 42, ๆ 22.

59 Ghana 4-16 Apr. 2005; Rwanda 18-30 Apr. 2005; Kenya 3-14 Oct. 2005, 10-14 April 2006; South Africa 9-25 July 2006; Algeria 10 Nov.-5 Dec. 2006, 3-14 March 2007; Benin 18 July-7 Aug. 2007.

60 Provisional list of partner institutions for the APRM, NEPAD/APRM/FORUM/022004/listPIs/Doc7.C, attached to Communiqué issued at the APR Forum, 13 February 2004, supra note 29.

61 GHANA REPORT, supra note 48. The report is 153 pages, with a five-page government response and a 127-page Program of Action attached.

62 African Peer Review Mechanism, Country Review Report of the Republic of RWANDA (June 2006) available at http://www.afrimap.org/english/images/documents [hereinafter RWANDA REPORT] Though it is dated June 2006, it was written directly after the country review mission in April 2005. The report is 131 pages long, with a forty-page government response and a thirty-page Program of Action. This version of the report was replaced with a new version which included some changes to the appendixes in September 2006. However, the substance of the report remained the same. See COUNTRY REVIEW REPORT OF THE REPUBLIC OF RWANDA (Nov. 2005), available at http://www.nepad.gov.rw/docs [hereinafter 
RWANDA REPORT II]

63 KenYA REPORT, supra note 1 at V-VI. The report is 258 pages, with a sixty-eight-page government response and an eighty-one-page Program of Action.

64 In the case of Rwanda, the Panel included an appendix setting out its response to the comments made by President Kagame at the Forum, see RWANDA REPORT, supra note 62, at 172. This appendix was removed from the final report, see RWANDA REPORT II, supra note 62.

65 Ghana National Program of Action 2005-2008 (June 2005); Rwanda’s Program of Action 2005-2008; The Kenya Program of Action (June 2006).

66 See, e.g., His Excellency Hon Mwai Kibaki, C.G.H., M.P., President and Commander-inChief of the Armed Forces of the Republic of Kenya, at the African Peer Review Forum in Banjul, The Gambia (30th June 2006), available at http://www.statehousekenya.go.ke/speeches/kibaki/june06/2006300601.htm. The power point presentation of Graca Machel, the Panel member responsible for the Kenya review is available at http://www.aprmkenya.org/index.php.

67 http://www.nepad.org; http://www.aprmkenya.org; http://www.naprm-gc.org; http://www.nepad.gov.rw. Some of these web sites are unfortunately not regularly updated. At the time of writing the country review reports on Algeria and South Africa had not yet been published.

68 Communiqué issued at the end of the $7^{\text {th }}$ Summit of the Committee of Heads of State and Government Participating in the African Peer Review Mechanism [APR Forum], 1 July 2007.

69 RWANDA REPORT II, supra note 62, appendix IV, 185-87.

70 Id. at 187.

71 APRM Base Document, supra note 43, ๆ 25.

72 It is noteworthy that copies of the country review reports were not available for the parliamentarians.

73 See, e.g., Christof Heyns \& Waruguru Kaguongo, Constitutional Human Rights Law in Africa, 22 S. Afr. J. Hum. RTs. 673 (2006).

74 Constitutive Act of the African Union, art. 3(h) available at http://www.au2002.gov.za/docs/key_oau/au_act.htm.

75 See, e.g., Heyns \& Killander, supra note 4; Amanda Lloyd \& Rachel Murray, Institutions with Responsibility for Human Rights Protection under the African Union, 48 J. AFR. L. 165 (2004).

76 NEPAD Framework Document, supra note 7, ๆ 67. 
77 Manby, supra note 19. See also Sabelo Gumedze, The NEPAD and Human Rights, 22 S. AFR. J. HuM. RTS. 144 (2006).

78 See, e.g., Amartya Sen, Development as Freedom (1999), United NATiOnS

Development Programme, Human Development Report 2000 (2000).

79 This follows the list of instruments included in OSCI and the Questionnaire. These also include many non-binding instruments. The distinction between binding and non-binding instruments is not always clear in the reports.

80 KENYA REPORT, supra note 1, at 256.

81 Id.

82 Concluding Observations of the Human Rights Committee, Consideration of Reports Submitted by States Parties Under Article 40 of the Covenant, U.N. GOAR, Hum. Rts. Comm., 83d Sess., U.N. Doc. CCPR/CO/83/KEN, I 18 (2005) [hereinafter Concluding Observations].

83 RWANDA REPORT, supra note 62, ๆ 84.

84 GHANA REPORT, supra note 48, ch. 2 ๆ 13.

85 KENYA REPORT, supra note 1, at 61.

86 GHANA Report, supra note 48, ch. 2, ๆๆ 13, 54.

87 KENYA REPORT, supra note 1, at 61.

$88 \mathrm{Id}$. at 257. For information on state reporting see the Office of the United Nations High Commissioner for Human Rights, available at www.ohchr.org, and the African Commission on Human and Peoples' Rights available at www.achpr.org. Kenya has never submitted reports to the CERD and CAT Committees. Kenya submitted its first report to the Committee on Economic, Social and Cultural Rights (CESCR Committee) in 1993, but the Committee requested a new initial report prepared according to the guidelines. To date no such report has been submitted. Kenya has submitted two reports to the Human Rights Committee (HRC), the latest in 2004. HRC published its concluding observations on the report in April 2005 and requested further information within a year. Kenya submitted the requested follow-up report in June 2006. Kenya has submitted three reports to the CEDAW Committee, the latest in March 2006. Kenya’s 2000 report was examined in January 2003. Kenya has reported twice to the Committee on the Rights of the Child (CRC Committee). Its initial report was examined in September 2001. Examination of its second periodic report, received in September 2005, is pending. Kenya submitted its initial report to the African Commission on Human and Peoples' Rights in 2006, fourteen years after ratifying the Charter. Ghana has never submitted reports to the HRC or the CESCR and CAT Committees, but has reported twice to the CEDAW

Committee. The third to fifth periodic report, submitted in February 2005, was examined by the Committee in August 2006, almost fifteen years after Ghana’s previous report had been 
examined. Ghana's latest report to the CERD Committee was examined in March 2003. Ghana’s second periodic report to the CRC Committee was submitted in March 2004 and examined by the Committee in January 2006. The previous report had been examined by the Committee in 1997. Ghana's second report to the African Commission on Human and Peoples' Rights was examined by the Commission in April 2001. Rwanda has not reported on implementation of ICCPR and ICESCR since 1987. The latest report to the CEDAW Committee was an exceptional oral report in January 1996. The latest report on CERD was examined in March 2000. The second periodic report of Rwanda to the CRC Committee was examined in May 2004. Rwanda has submitted four reports to the African Commission on Human and Peoples' Rights. The latest report is dated March 2005.

89 A 2003 UN interagency meeting on human rights considered that development programming should be "informed by the recommendations of international human rights bodies and mechanisms.” See The Human Rights Based Approach to Development Cooperation: Towards a Common Understanding Among the UN Agencies, in Philip Alston, Ships Passing in the Night: The Current State of the Human Rights and Development Debate Seen Through the Lens of the Millennium Development Goals, 27 HuM. RTS. Q. 755, 801 (2005).

90 Ghana is the only of the three countries that allows its citizen the right to complain to the Human Rights Committee and the Committee Against Torture, though no such complaints have been considered. However, all state parties to the African Charter on Human and Peoples' Rights allow for individual complaints to the African Commission, which has decided cases against more than 30 African countries, including Ghana, Kenya and Rwanda. The APRM reports do not consider these cases. One reason could be that the most recent decision, available at the time of the reviews, finding a violation by any of the countries date back to 2000 .

91 The UN High Commissioner for Human Rights encourages countries to extend a standing invitation to the UN special procedures. Of African countries only Sierra Leone and South Africa have done this. Kenya received a visit from the UN special rapporteur on housing in 2004 and the special rapporteur on indigenous rights in 2006. However, the government has not yet responded to requests from three other special rapporteurs to visit the country, one of whom requested a visit in 2003. Ghana was visited by the Special Rapporteur on Violence against Women in July 2007 and has received two requests for visits to which it has not responded.

92 Questionnaire, supra note 29.

93 KENYA REPORT, supra note 1, at 66-67.

94 GHANA REPORT, supra note 48, ch. 2, ๆ 26.

95 RWANDA REPORT, supra note 62, ๆ 88.

96 KENYA REPORT, supra note 1, at 67.

97 The Economist Intelligence Unit Democracy Index 2006 weighs five factors that affect the degree of democracy in a country: electoral process and pluralism, functioning of government, 
political participation, political culture and civil liberties. Laura Kekic, The Economist Intelligence Unit's Index of Democracy, in ECONOMIST, THE WORLD IN 2007 (2006).

98 GHANA RePORT, supra note 48, ch. 2, ๆ 34. The recommendations and PoA in this context only deal with support to governance institutions with regard to civic education.

99 Id. ch. 2, ๆ 42. See also PoA, Objective 3.

100 GHANA REPORT, supra note 48, ch. 2, ๆ 31.

101 Id. ch. 2, ๆ 41.

102 RWANDA REPORT, supra note 62, \103.

103 Id. ๆ 106.

104 Id. $\uparrow 107$.

105 It should be noted that Rwanda did not present a PoA sorted under objectives. For "purpose of clarity and analysis" the APRM Secretariat arranged the PoA by objective.

106 Commission on Human Rights and Administrative Justice (CHRAJ, Ghana) available at http://www.chrajghana.org; Kenya National Commission on Human Rights available at http://www.knchr.org; National Human Rights Commission (Rwanda) available at http://www.hri.ca

107 GHANA REPORT, supra note 48, ch. 2, box 2.3.

108 Id. ch. 2, ๆ 36.

109 Noteworthy is the omission of peoples' rights despite their importance in the main African human rights instrument, the African Charter on Human and Peoples’ Rights.

110 The GHANA REPORT and RWANDA REPORT both devote three pages to this objective and the KENYA REPORT eight pages. GHANA REPORT, supra note 48, ch. 2, ๆף 43-54; RWANDA REPORT, supra note 62, ๆๆ108-117; KeNYA REPORT, supra note 1 at 77-84.

111 GHANA REPORT, supra note 48, ch. 2, 凤 44.

112 Id. ch. 2, ๆ 46.

113 Id. ch. 2, ๆ 54.

114 The following issues are listed under Objective 3 in the PoA: access to justice, safety and security of life and property, capacity of CHRAJ to prosecute its mandate, cultural practices harmful to women, child trafficking and child labor, under representation of women in public life, violations of the rights of the disabled. 
115 RWANDA REPORT, supra note 62, ch. 2, box 2.1.

116 Id. ๆ 116. The Gacaca tribunals, which have been set up to speed up the genocide trials, are based on a traditional dispute settlement mechanism.

117 KeNYA REPORT, supra note 1 , at 82.

118 Concluding Observations, supra note 82, ๆ 16

119 Id. ๆ 18.

120 KENYA REPORT, supra note 1 , at 84.

121 RWANDA REPORT, supra note 62, ๆ 119.

122 Id. ๆ 121.

123 KENYA REPORT, supra note 1 , at 91.

124 Id. at 331.

125 GHANA REPORT, supra note 48, ch. 2, ๆ 64.

126 RWANDA REPORT, supra note 62, ๆ 140.

127 GHANA REPORT, supra note 48, ch. 2, ๆ 96.

128 Id. ๆ 89.

129 KENYA REPORT, supra note 1, at 107.

130 Id. at 336.

131 RWANDA REPORT, supra note 62, ๆ 149.

132 RWANDA REPORT, supra note 62, Appendix III, Objective 8

133 GHANA REPORT, supra note 48, ch. 2, ๆ 105.

134 Id. ๆ 106.

135 On the response of UNHCR to the situation for refugees in Ghana see UNITED NATIONS High COMMISSIONER FOR HuMAN RightS, GLOBAL REPORT 221-26 (2005). As stated in the report, Ghana hosts more than 50,000 refugees, mainly from Liberia, id. at 222.

136 RWANDA REPORT, supra note 62, ๆ 156.

137 Id. ๆ 153. 
138 See, e.g., PATRICK Bond, LoOting Africa 125-28 (2006).

139 KENYA REPORT, supra note 1, at 133-34.

$140 \mathrm{Id}$. at $135-37$.

141 International Monetary Fund, Poverty Reduction Strategy Papers (PRSP), available at http://www.imf.org/external/np/prsp/prsp.asp.

142 Algeria, Angola, Egypt, Gabon, Mauritius, South Africa, and Sudan.

143 KENYA REPORT, supra note 1, at 134.

144 GHANA REPORT, supra note 48, ch. 3, ๆ 1 I 33-35.

145 Id.

146 RWANDA REPORT, supra note 62, ๆ 194.

147 Id. ๆศ 185-86.

148 GHANA RePORT, supra note 48, ch. 3, 9 82. This recommendation is not given in the Rwanda and Kenya Reports.

149 Objective 4: Fight corruption and money laundering.

150 RWANDA REPORT, supra note 62, ๆ 214. See also ๆ 134.

151 Economic governance and management, Objective 5.

152 The RWANDA REPORT notes the likelihood of fiscal losses, RWANDA REPORT, supra note 62, I 219. The PoA includes cost-benefit analysis concerning regional integration, following a recommendation of the Panel, id. I 222. See also Aimable Twahirwa, Controversy Over Plan to Join East African Economic Community, IPS NEws, 5 Nov. 2006, available at http://ipsnews.net/africa/nota.asp?idnews=35374.

153 RWANDA REPORT, supra note62, ๆף 314-25.

154 KenYa REPORT, supra note 1, at 184-93.

155 GHANA REPORT, supra note 48, ch. 5, ๆ 53.

156 Id.

157 Id. ๆๆ 8-9.

158 Id. ๆ 41. 
159 Id. ๆ 51.

160 Id. ๆ 54.

161 By 2006 teachers should be paid at least US\$ 2 per day. Id. ๆ 236.

162 RWANDA REPORT, supra note 62, ๆ 109.

163 Id. ๆ 110.

164 Id. ๆ 394, 397

165 Id. at 204.

166 Id. ๆף 394, 397.

167 Id. ๆ 397.

168 Id. $\uparrow 410$.

169 Id. ๆ 397.

170 Access to land was not included in OSCI, but is included in the Questionnaire.

171 GHANA REPORT, supra note 48, ch. 5, ๆ 67.

172 Id. ๆ 68.

173 KeNYA REPORT, supra note 1, at 234.

174 RWANDA REPORT, supra note 62, ๆ 422.

175 KENYA REPORT, supra note 1, at 239.

176 Id. at 251.

177 Robert Mukombozi \& Ignatius Ssuuna, APR Recommendations to Cost US\$ 95 Million, NEW TIMES, July 16, 2006, available at http://www.rwandagateway.org/article.php3?id_article=2271.

178 Kojo Busia, Ghana's APRM: Processes and Preliminary Outcomes (2006), available at www.pacweb.org/e/images/stories/documents/aprm\%20update\%20for\%20ghana.pdf.

179 Guidelines, supra note 42, ๆ 18(v).

180 KENYA REPORT, supra note 1, at 96.

181 Id. at 97. 
182 For such recommendations see DRAFT KEY IsSUES, supra note 68.

183 In dealing with the rights of children, the Panel recommends that Rwanda ratify the African Charter on the Rights and Welfare of the Child. This is despite the fact Rwanda ratified this treaty already in May 2001. RwANDA REPORT, supra note 62, ๆ 149; see also 9 ๆ 145-46. The fact that Rwanda has ratified the treaty is clear from the country review report itself, see id. $\uparrow$ 81, but no one in the country review mission seems to have taken note of this.

184 See, e.g., His Excellency Hon Mwai Kibaki, supra note 66.

185 Guidelines, supra note 42, ๆ 12.

186 The Panel recommends that Ghana adopt an action plan for ratification of international human rights treaties. This is reflected in the PoA, but a national human rights action plan obviously entails much more.

187 See, e.g., Goran Hyden, African Politics in Comparative Perspectives (2006).

188 Douglas Cassel, Does International Human Rights Law Make a Difference?, 2 CHI. J. INT’L L. 121, 124 (2001).

189 The current guidelines for state reporting to the African Commission are not adequate. It is suggested that the African Commission would keep the APRM process in mind in the long overdue process of revising the guidelines. See African Commission on Human Rights, supra note 88.

190 On state reporting under the African Charter see, e.g., Kofi Quashigah, The African Charter on Human and Peoples' Rights: Towards a More Effective Reporting Mechanism, 2 AFR. HuM. RTS. L. J. 261 (2002), Malcolm Evans, Tokunbo Ige \& Rachel Murray, The Reporting Mechanism of the African Charter on Human and Peoples' Rights, in THE AFRICAN CHARTER ON Human And Peoples’ Rights: The System in Practice, 1986-2000 36 (Malcolm Evans \& Rachel Murray eds. 2002).

191 Under African Charter, art. 62 of the every state party is required to submit a report on its implementation of the Charter every second year. The African Commission could declare that APRM reporting as suggested here would be in compliance with the requirements of the Charter.

192 Each participating country must pay a minimum of US\$ 100,000 to the APRM Secretariat. In addition all national costs for the process are paid by the participating country, even though some donors, for example the UNDP, offer assistance. For more information on the financing of the APRM process see The African Peer Review Mechanism (APRM): Africa's Innovative Thinking on Governance, supra note 30, at 5-6. 